\title{
PRESERVATION OF ENVIRONMENT IN TIMES OF NON-INTERNATIONAL ARMED CONFLICT. LEGAL FRAMEWORK, ITS SUFFICIENCY AND SUGGESTIONS
}

\author{
Indrè Lechtimiakytė \\ University of Groningen, Faculty of Law \\ PO Box 729700 AB Groningen \\ E-mail: indre.lechtimiakyte@gmail.com \\ LL.M in International Law and Law of International Organizations. \\ Mykolas Romeris University \\ Law and Management, LLB
}

Received on 24 May, 2013; accepted on 24 August, 2013

doi:10.13165/JUR-13-20-2-11

\begin{abstract}
Environmental protection in times of armed conflicts, irrespective internal or international, is rarely considered as a prioritized concern. Due to the concept of state sovereignty, this is especially problematic when examining interaction of warfare and environmental protection in non-international hostilities. Not only it is challenging to find any exhaustive and explicit legal provisions regulating the matter, but this issue has also been forgotten by international legal scholars. Therefore, in this article the author reviews written and customary norms laid down in documents of various branches of international law, such as international humanitarian law, human rights law, environmental law and international criminal law, which directly or by way of interpretation may favour environmental protection in times of internal armed conflict. This is to be done in order to gather information about the sufficiency of legal framework on preservation of the environment in times of noninternational armed conflicts. After doing this research, a few possible means to improve current legal framework are suggested. The author suggests to impose civil liability, enact new comprehensive document, initiate changes in international criminal law and other.
\end{abstract}


Keywords: Environmental law, Humanitarian law, International criminal law, International human rights law, non-international (internal) armed conflict, insufficient international regulation, legal vacuum.

\section{Introduction}

Although since its very beginning the purpose of International Humanitarian Law (hereinafter - IHL) was to make war more humane ${ }^{1}$, the international community is increasingly concerned with the protection of objects that are not directly related with human suffering. An important anxiety in terms of IHL and its application concerns the preservation of environment in times of armed conflict. The environment itself was not even mentioned in international documents regulating conduct in war until Additional Protocol I (hereinafter - AP I) of Geneva Conventions (hereinafter - GC's) came into force in 1977. With the realization of an inevitable need to regulate protection of the environment during armed conflicts, it, however, was left to do for the norms, such as Articles 35(3) and 55 of AP I, which are subjects of intensive criticism. ${ }^{2}$

According to the author's opinion, criticism of these norms should not be the most prioritized concern. An extremely sensitive issue and quite a remarkable gap in IHL is questionable sufficiency of regulation for protection of environment during noninternational armed conflict (hereinafter - NIAC). Gaps of international law usually attract attention of legal scholars. They try to elaborate on legal contributions and disputes, how it would be possible to solve the problem. This, however, is not the case in environmental protection in times of NIAC. After doing some research, the author came to the conclusion, that there are very few contributions regarding this issue. Scholars tend to focus on the criticism of Articles 35 (3) and 55 of the AP I, analyze norms applicable to the protection of environment in IACs, and are quite reluctant to get into a deeper analysis of internal armed conflicts. Nonetheless, it is generally acknowledged by most of them that legal regulation tends to be insufficient on this matter. ${ }^{3}$

1 Verwey, W. D. Protection of the Environment in Times of Armed Conflict: In Search of a New Legal Perspective. Leiden Journal of International Law. 1995, 8: 7-40; Solis, G. D. The Law of Armed Conflict. International Humanitarian Law in War. Cambridge: Cambridge University Press, 2010, p. 23.

2 The criticism is mostly based on high threshold of applicability of API. Peterson, I. The Natural Environment in Times of Armed Conflict: A Concern for International War Crimes Law? Leiden Journal of International Law. 2009, (22): 225-343; Verwey, P., supra note 1, p. 10; Solis, G. D., supra note 1, p. 131, 138; Bothe, M.; Bruch, C.; Diamond, J. and Jensen, D. International Law Protecting the Environment during Armed Conflict: Gaps and Opportunities. International Review of the Red Cross. 2010 (92): 576-578. Kiss, A. International Humanitarian Law and the Environment. Environmental Policy and Law. 2001, (31): 223-231.

3 Verwey, P., supra note 1, p. 29; Bouvier, A. Protection of the Environment in Time of Armed Conflict. 19921001 Report submitted for the 4 $7^{\text {th }}$ session of the United Nations General Assembly, part 5;

Bouvier, A. Protection of the Environment in Time of Armed Conflict. 19911231 International Review of the Red Cross. 1991, 285; Gasser, H. P. For Better Protection of Natural Environment in Armed Conflict: a Proposal for Action. American Journal of International Law. 1995, (89): 637-643;

Henckaerts, J. M. Towards Better Protection for the Environment in Armed Conflict: Recent Developments 
Therefore, this article examines the question whether the current legal framework on the preservation of environment in times of non-international armed conflicts, given the absence of explicit and direct provisions, nonetheless may be deemed as sufficient for this protection. This is to be achieved by analyzing if there are any explicit or implicit statutory obligations dispersed in other than IHL branches of written or customary law that may contribute to the integrity of the framework.

The underlying problem of the possible legal vacuum and the lack of existing legal framework on the above mentioned issue in written and customary norms, directly and indirectly regulating the protection of the environment in internal armed conflicts, will be examined first. Afterwards, an answer to the question "Is the legal framework, provided in international humanitarian and other branches of law, sufficient for the sound protection of the environment in times of non-international armed conflict?" may be found. In the final part of this research, the author elaborates on possible ways to improve the situation in terms of legislature and enforcement.

\section{Existing Relevant Law}

Provisions relevant to the research can be found in documents of human rights law, international criminal law, international environmental law and international humanitarian law. Customary humanitarian law provides customary rules, when application of written (treaties') obligations due to their vagueness and/or high threshold of applicability is complex. The mechanism of environmental protection in internal armed conflicts is an outcome of different types of law merging together for the sake of environmental preservation.

\subsection{Legal Framework}

\subsubsection{Geneva Conventions and its protocols}

Despite the fact that Geneva Conventions do not include environmental norms, Additional Protocol I, which applies during times of international armed conflicts, made a huge step forward with Articles 35 (3) and 55.

Art. 55 establishes a general obligation to protect the environment during armed conflict, but this obligation for belligerent states is aimed at the protection of civilian population. Article 35(3) is meant to protect environment as such. ${ }^{4}$ Although a subject to criticism mostly referring to the high threshold of applicability, these articles were a first step towards the recognition of the necessity of environmental norms in the law of war.

in International Humanitarian Law. The Review of European Community and International Environmental Law. 2000, (9): 13-19; Gleditch, N.P. Armed Conflict and the Environment: A Critique of the Literature. Journal of Peace Research. 1998, (35): 381-400; Brunch, C.E. Introduction. Environmental Consequences of War. Legal, Economic and Scientific Perspectives. Cambridge: Cambridge University Press, 2000, p. 43.

4 Bouvier, A. Protection of the Environment in Time of Armed Conflict. International Review of the Red Cross. 199112 31, 285, part C. 
Because of the notably narrow regulation of Common Article 3 and the majority of the conflicts after 1945 being internal, the adoption of Additional Protocol II (hereinafter AP II) was more than necessary. Despite the absence of explicit environmental norms in Additional Protocol II, an implicit environmental provision exists. Article 14 prohibits attacks against "foodstuffs, agricultural areas for the production of foodstuffs, crops, livestock, drinking water installations and supplies and irrigation works" ${ }^{\text {"5 }}$, objects that are ,indispensable to the survival of the civilian population. ${ }^{\text {" }}$ Article 15 prohibits attacks against dangerous forces, such as dams, dykes and nuclear electrical generating stations, if ,attack may cause the release of dangerous forces and consequent severe losses among the civilian population." 7 These two provisions are clearly aimed at protection of the civilian population, nonetheless, environmental impact of the provisions is also evident.

Another reason of AP II not meeting the expectations is that an internal armed conflict has to meet the high threshold requirements to fall under the scope of application of AP II. ${ }^{8}$ Article 1(1) lays down an additional condition to the ones already present in Common Article 3: dissident armed forces or other organized groups have to be under responsible command and exercise control of the part of the territory. Requirements are set up as cumulative, therefore, it is difficult to find an internal conflict meeting all of them. Therefore, AP II has never been applied in neither of international judicial institutions, which proves questionable contribution to the protection of the environment in times of internal armed conflict.

\subsubsection{Disarmament and weapons' treaties and their impact on environmental protection in NIACs}

Naturally, disarmament and weapons' treaties are not designed specifically to protect the environment. Nonetheless, the impact assessment shows that in case of using weapons of prohibited or restricted use, such effect would be inevitable. Disarmament treaties can be considered as part of International Humanitarian Law; however, some of them also comprise provisions that indicate the application during peace time or under "any circumstances".

1977 Protocol Additional to the Geneva Conventions of 12 August, 1949, and relating to the Protection of Victims of Non-International Armed Conflicts (Protocol II) (adopted 8 June, 1977, entry into force 7 December, 1978). 1125 U.N.T.S. 609/ [1991] ATS 30/16 ILM 1442 (1977), Article 14.

6 Ibid.

7 Ibid., Art. 15.

8 Solis, G. D. supra note 1, p. 131, 138.

9 The Convention on the prohibition of the Development, production and Stockpiling of Bacteriological (Biological) and Toxin Weapons and on Their Destruction (adopted 10 April, 1972, entry into force 26 March, 1975). 1015 U.N.T.S. 163 / [1977] ATS 23 / 11 ILM 309 (1972), Article 1; The Convention on Prohibitions or Restrictions on the Use of Certain Conventional Weapons which may be deemed to be Excessively Injurious or to have Indiscriminate Effects (adopted 10 October, 1980, entry into force 2 December, 1983). 1342 U.N.T.S. 137/ [1984] ATS 6 / 19 ILM 1823 (1980), Article 1; 1980 protocol in Prohibitions or Restrictions on the Use of Mines, Booby-Traps and Other Devices (adopted 10 October, 1980, entry into force 2 December, 1983) 1342 U.N.T.S. 168, 19 I.L.M. 1529, Article 6 (2); 1980 Protocol on Prohibitions or Restrictions on the Use of Incendiary Weapons (adopted 10 October, 1980, entry into force 2 December, 1983). 1342 U.N.T.S. 171, 19 I.L.M. 1534 Article 2 (1) and 2 (2); The 1993 Convention 


\subsubsection{The 1971 UN Convention on the Prohibition of the Development, Production and Stockpiling of Bacteriological (Biological) and Toxin Weapons and on Their Destruction}

The purpose of protecting the population and the environment is expressed in Article 2 of the Convention: "In implementing the provisions of this Article all necessary safety precautions shall be observed to protect populations and the environment". The convention prohibits the use of biological agents "in any circumstances" 10 if it does not have justification for using it for peaceful purposes. It suggests that the Convention applies in times of non-international armed conflict. Part 2 of Art. 1 specifically prohibits hostile purposes and using bacteriological agents in war.

At the time of writing, 165 states were parties to the Bacteriological (Biological) Weapons Convention (hereinafter - the BWC) and 12 states were signatories to it. ${ }^{11}$ Although criticized because of its indeterminate language, such as the absence of quantities and parameters to determine when is the substance being used to the peaceful purpose, which may give ground for circumvention, ${ }^{12}$ it is a contribution to the environmental protection in NIAC.

\subsubsection{The 1977 Convention on the Prohibition of Military or Any Other Hostile Use of Environmental Modification Techniques (ENMOD)}

In terms of the environmental protection, this treaty prohibits technical and scientific manipulation of natural processes, which may affect the environment, and when this manipulation is used as a weapon. ${ }^{13}$

Art. 1 of the Convention does not make the distinction between IACs and NIACs. On the contrary, it says ,not to engage in military or any other hostile use of environmental modification techniques" ${ }^{\text {"14 }}$ (emphasis added). Presumably applicable in NIAC, the basic obligation in Article 1 is constructed very similarly to the wording of AP I of GC's. There is one crucial difference though. While AP I requirements „Widespread, long lasting and severe" are cumulative, ENMOD convention uses conjunction "or", which implies that only one of the requirements can be sufficient for the Convention to apply.

Being of the lower threshold than AP I, and, moreover, applicable in NIAC, the ENMOD convention has its disadvantages. Firstly, it is not created for the protection of the environment. Careful reading of Article 1 (1) shows that it seeks to prevent injury

the Prohibition of the Development, Production, Stockpiling and Use of Chemical Weapons (adopted 3 September, 1992, entry into force 29 April, 1997). 1974 U.N.T.S. 317, Article 1.

10 The Convention on the prohibition of the Development, production and Stockpiling of Bacteriological (Biological) and Toxin Weapons and on Their Destruction, op. cit.

11 Official Website of International Committee of the Red Cross Geneva, 2013 [interactive]. [accessed on 06-06-2013]. <http://www.icrc.org/ihl.nsf/INTRO/450?OpenDocument>.

12 Solis, G. D. supra note 1, p. 607-611.

13 Verwey, W. D., supra note 1, p. 16.

14 Convention on the Prohibition of Military or Any Other Hostile Use of Environmental Modification Techniques (adopted 10 December, 1976, entry into force 5 October, 1978). 1108 U.N.T.S. 151. 
of another state party, not the environment per se. ${ }^{15}$ Tarasofsky names several points of criticism of ENMOD: „No prohibition exists against damaging environment of nonparties or to the global commons. [...] it does not prevent testing and development of environmental modification techniques." ${ }^{16}$ This argument, however, can be rebutted by saying that in case of damage while using techniques for non-hostile purposes, international environmental law and its prohibitions apply. However, the above described imperfections of the Convention may explain the fact that only 76 states are parties to it. Therefore, the ENMOD convention cannot be considered as a strong instrument contributing to the environmental protection in NIACs.

\subsubsection{The 1980 Certain Conventional Weapons Convention and its protocols}

The Certain Conventional Weapons Convention (hereinafter - the CCWC) is based on three general principles of IHL - unnecessary suffering, distinction and limited means of warfare. ${ }^{17}$ Three original protocols on non-detectable fragments, mines, booby-traps and other devices and incendiary weapons were adopted together with the treaty in 1980. Additional two on laser weapons and explosive remnants of war were enacted in 1996 and 2001 respectively. Initially, the treaty and its three original protocols applied only in IAC.

Talking about crucial steps in the development of international law documents applicable in NIAC, it should be emphasized that the amendment of the Article 1(2) ${ }^{18}$ extended the CCWC and its protocols' application to the NIAC that are described in Common Article 3. Common Article 3, as it is known, sets the lower threshold for the internal conflict to be considered as such than does the AP II. This broadens the scope of applicability to the nowadays' most common armed conflicts. Preamble of the Convention recalls prohibition "to employ methods or means of warfare which are intended, or may be expected, to cause widespread, long-term and severe damage to the natural environment." 19

The CCWC Protocol III Concerning Incendiary Weapons refers to prohibition „to make forests or other kinds of plant cover the object of attack by incendiary weapons." ${ }^{20}$ Reference is also made to the principle of distinction, when such prohibition fails to exist when using natural elements for military purposes. Other protocols do not refer

15 Tarasofsky, R. G. Legal Protection of the Environment during International Armed Conflict. Netherlands Yearbook of International Law. 1993: 17-79. Also see p. 47.

16 Ibid.

17 For this section, see generally Solis, G. D. supra note 1, p. 578-591.

18 Amendment of the Article 1.2 of 1980 Convention on Prohibition or Restrictions on the Use of Certain Conventional Weapons which may be Deemed to be Excessively Injurious or to have Indiscriminate Effects (adoption 21 December, 2001, entry into force 18 May, 2004) 2260 U.N.T.S. 82.

19 The Convention on Prohibitions or Restrictions on the Use of Certain Conventional Weapons which may be deemed to be Excessively Injurious or to have Indiscriminate Effects, supra note 9, Preamble.

20 The Chemical Weapons Convention Protocol on Prohibitions or Restrictions on the Use of Incendiary Weapons (Protocol III), supra note 9, Article 2(4). 
to the environment by any means directly or indirectly. However, prohibition of such indiscriminate weapons itself is a type of the environmental protection, especially regarding its application in NIAC. Unfortunately, only 114 states have signed the Convention, and only 75 states recognize the application of the Convention in NIAC, as in amended article $1(2){ }^{21}$

\subsubsection{The 1993 Convention on the Prohibition of the Development, Production, Stockpiling and Use of Chemical Weapons}

Convention of Chemical Weapons (hereinafter - the CCW) regulates use of toxic chemicals and their precursors. The prohibition is established in wording quite similar to the BWC - "never under any circumstances." 22 In Art. 2 (9), this Convention indicates peaceful purposes of using chemical substances that are not prohibited. Therefore, inference can be made that the Convention of Chemical Weapons is applicable in times of peace, international and non-international armed conflicts. In Article 7, the Organization for the Prohibition of Chemical Weapons is established, which makes the Convention with its 188 parties and two signatories ${ }^{23}$ nearly universal treaty with the mechanism of compliance. Next to the safety of people, the CCW explicitly mentions the protection of the environment as the "highest priority" while transporting, sampling, storing and destructing chemical weapons and production facilities. ${ }^{24}$

\subsubsection{Applicability of International Environmental Law in Times of Non-International Armed Conflict}

While analyzing environmental issues, it is logical to refer to binding environmental treaties and environmental soft law instruments. Does the environmental law continue to apply during the internal armed conflict?

In the legal doctrine, one of the justifications for terminating the application of certain treaties is the principle clausula rebus sic stantibus. Treaties become inapplicable due to the fundamental change of circumstances. Armed conflict can inevitably be considered as such a circumstance. Moreover, in a case of an armed conflict, principle lex specialis, derogat lexi generalis applies. War time laws are undoubtedly lex specialis and prevail over peace time laws. Therefore, it is usually considered that peacetime treaties cease to apply in times of hostilities. This is highly questionable due to the following reasons.

Voneky writes that the sufficient state practice shows that for certain kinds of treaties clear rules remain applicable between belligerent states. These rules are applied

21 Official Website of International Committee of the Red Cross. Geneva, 2013 [interactive]. [accessed on 06-06-2013]. <http://www.icrc.org/ihl.nsf/WebSign?ReadForm\&id=600\&ps=P $>$.

22 The 1993 Convention on the Prohibition of the Development, Production, Stockpiling and Use of Chemical Weapons, supra note 9.

23 Official Website of International Committee of the Red Cross. Geneva, 2013 [interactive]. [accessed on 06-06-2013]. <http://www.icrc.org/ihl.nsf/INTRO/553?OpenDocument>.

24 The 1993 Convention on the Prohibition of the Development, Production, Stockpiling and Use of Chemical Weapons, supra note 9. Articles IV (10), V (11), VI (3). 
in particular when "(1) treaties expressly provide for continuance during war, (2) treaties are compatible with the maintenance of war, (3) treaties creating international regime or status, (4) human rights treaties and (5) ius cogens rules and obligations erga omnes. "25 However, treaties rarely address application during an armed conflict, or can, as peace time treaties create regime (emphasis added). Treaties compatible with the maintenance of war raise less questions, so do human rights treaties, which are proclaimed not to cease to apply in a case of an armed conflict by the International Court of Justice. ${ }^{26}$ Human rights treaties, though being constructed to the protection of human rights, protect the environment via proper exercising of the former. Since the above mentioned treaties are primarily meant to apply in the peacetime, it is logical that they do not make the distinction between the NIAC and the IAC. Therefore, if they fall in the concept of the treaties, remaining to apply during the times of engaging in hostilities, they apply in the NIACs, as well.

Attention has to be paid to soft law instruments, such as Stockholm Declaration ${ }^{27}$, Rio Declaration, ${ }^{28}$ World Charter for Nature, the UN GA resolution 47/3729 and also the UNESCO convention for the protection of the World Cultural and Natural Heritage. However, principles established in the soft law are not binding. In order to invoke any legal obligations, these principles have to approach international customary law stage. In times of an armed conflict, it ,could not reasonably meet the test of general practice and opinio juris." ${ }^{\text {(30 }}$

Continued applicability of International Environmental Law is of a grave importance, showing rapid evolution and spread of environmental awareness. Nonetheless, it still lacks efficiency to provide the proper protection during times on the NIAC.

\subsubsection{Statutes of International Criminal Tribunals and environmental protection}

Any kind of prohibition functions the best if it criminalizes the conduct. Thus, leaving aside Nuremberg, when modern IHL and environmental norms were only started to be established in treaties, a look can be taken at the statutes of the International Criminal Tribunal for Former Yugoslavia (hereinafter - the ICTY), the International

25 Voneky, S. Peacetime Environmental Law as a Basis for State Responsibility. Environmental Consequences of War. Legal, Economic and Scientific Perspectives. Cambridge: Cambridge University Press, 2000, p. 190-225.

26 Legal Consequences of the Construction of Wall in the Occupied Palestinian Territory. International Court of Justice, Advisory Opinion I. C. J. Reports. 2004, p. 136, para. 106.

271972 Declaration of the United Nations Conference on the Human Environment (adopted at the United Nation Conference on Human Environment in Stockholm, 16 June, 1972). 11 I.L.M. 1416 (1972).

281992 Rio de Janeiro Declaration on Environment and Development (adopted at Rio de Janeiro Declaration on Environment and Development in Rio de Janeiro, 13 June, 1992). 31 I.L.M. 881 (1992).

29 General Assembly Resolution A/RES/47/37 of 19921125 [interactive]. [accessed on 06-07-2013]. $<\mathrm{http}: / /$ www.un.org/Depts/dhl/resguide/r47.htm>.

30 Bothe, M.; Bruch, C.; Diamond, J. and Jensen, D., supra note 2, p. 585. 
Criminal Tribunal for Rwanda (hereinafter - the ICTR) and the International Criminal Court (hereinafter - the ICC).

\subsubsection{Statutes of the ICTY and the ICTR}

Created to establish jurisdiction of the tribunals over the crimes committed during the very particular time in very particular area, statutes of the ICTY and the ICTR fail to explicitly name environmental damages in the list of crimes. By way of interpretation and especially bearing in mind the significance of environmental damage in the Former Yugoslavia, ${ }^{31}$ it can be inferred that environmental issues are covered, at least partially, by Article 3 of the statute of the ICTY and Article 4 of the statute of the ICTR. The former criminalizes the use of poisonous weapons, destruction of cities, devastation, seizure of property, destruction, willful damage done to historic monuments. The devastation can amount to the destruction of the protectable landscape; historical monuments can be partially incorporated into the natural environment or parts of the natural environment can be of historical value as such. The latter, Article 4 of the ICTR statute, however, is more difficult to interpret. In fact, there are no provisions whatsoever in the ICTR statute, that could be related to the environmental protection, which suggests that the conflict in Rwanda being completely internal brought up less, if any, environmental concern. Meanwhile, the situation in the Former Yugoslavia had some international features, thus allowed the applicability of some of the humanitarian laws regarding the environmental protection. However, it still leaves open the question whether the sufficient environmental protection can be based on the protection of particular areas, covered by the statutes of the ICTY and ICTR statutes, and whether such protection in these statutes exists.

\subsubsection{The Rome Statute}

One of the crimes, over which the ICC has jurisdiction, is in the Article 8(2)(b) (iv) described prohibition to launch an attack causing "widespread, long-term, and severe damage to the environment that would be clearly excessive to $[. .$.$] the military$ advantage anticipated." ${ }^{32}$ However, this ICC statute article is very controversial and does not favorably collaborate with this research for the environmental protection in times of the NIAC mostly due to its inapplicability in the NIAC. Articles 8(2)(c) and (e), that name crimes punishable within non-international armed conflicts, do not include environmental crimes in the list.

In 2000, Henckaerts wrote about the review conference of the Rome Statute, which could be an arena for discussions about extending applicability of war crimes relevant

31 Final Report to the Prosecutor by the Committee Established to Review the NATO Bombing Campaign Against the Federal Republic of Yugoslavia. The International Criminal Tribunal for Former Yugoslavia. 13 June, 2000 [interactive]. [accessed on 2013-06-07]. <http://www.icty.org/sid/10052/en>.

32 The Rome Statute for the International Criminal Court (adopted 17 July, 1998, entry into force 1 July, 2003). 2187 U.N.T.S. 90. Article 8 (2)(b)(iv). 
for the protection of the environment of the application in the NIAC. ${ }^{33}$ According to the rules laid down in the statute and its coming into force in 2002, such conference was supposed to be organized in 2009. It was opened in 2010; however, environmental issues were not on the agenda. ${ }^{34}$

\subsubsection{Human Rights treaties}

The link between human rights and the environmental law can be drawn from the perspective of the third generation human rights, right to the healthy environment being one of them. It is especially well developed under the European system in the jurisprudence of the European Court of Human Rights as indirect right, protected through the right to life, right to property and private life. The UN approach also affirms that ,the environment is a pre-requisite for the enjoyment of human rights." 35

The application of human rights treaties during an internal armed conflict is undisputable. Since Common Article 3 of the GCs and AP II establish the basic protection of human rights in times of the NIACs, some areas remain unregulated by law of an armed conflict as lex specialis. ${ }^{36}$ Therefore, the rights to private life and property remain the subjects of human rights law. Former rights are precisely those, from which environmental rights are derived. Pollution caused by noise, fume and various substances impact private life and health of people. Analogy can also be drawn with the theory mentioned in the section 1.1.4. It quoted Voneky confirming sufficient state practice for application of certain kinds of peace time treaties or provisions in times of an armed conflict. ${ }^{37}$ The above-mentioned rules of human rights treaties can be attributed to "treaties that are compatible with the maintenance of war." 38 Hence, it may be concluded that human rights law indirectly contributes to the sufficiency of environmental protection during the internal armed conflict because human rights' instruments' provisions regulating private life, property ${ }^{39}$ do not cease to apply. Absence of such provisions in humanitarian law does not deny the existence of rights as such. ${ }^{40}$ However, general principle of military necessity, which is certainly applicable in the NIACs, may easily overcome such contribution.

33 Hanckearts, J. M., supra note 3, p. 17.

34 Review Conference of the Rome Statute. Coalition to the International Criminal Court Kampala, 2010 [interactive]. [accessed on 06-06-2013]. $<$ http://www.iccnow.org/?mod=review $>$.

35 High Level Expert Meeting on the New Future of Human Rights and Environment: Moving the Global Agenda Forward. United Nations Environmental Programme. 2009 [interactive]. [accessed on 2013-0607]. <http://www.unep.org/environmentalgovernance/Events/HumanRightsandEnvironment/tabid/2046/ language/en-US/Default.aspx $>$.

36 Legal Consequences of the Construction of Wall in the Occupied Palestinian Territory. International Court of Justice, supra note 26, paras. 106-109.

37 Voneky, S., supra note 25.

38 Ibid.

39 Right to property, however, can be subjects of limitation during times of the emergency situation.

40 Hampson, F. J. The Relationship between International Humanitarian Law and Human Rights Law from the Perspective of a Human Rights Treaty Body. International Review of a Red Cross. 2008, (90): 549572. 


\subsection{Customary Law}

The aforementioned lack of clarity in treaties and written obligations suggest the further object of the study - customary international law. First of all, international customary humanitarian law helps with two main disadvantages we have faced when examining treaty obligations. Treaties only apply to states that have ratified them; consequently, it narrows down the geographical scope of application. Customary law rules are applicable to all parties to the conflict, despite its nature, or whether parties have ratified certain documents or not. ${ }^{41}$ It, therefore, fills up some gaps in the regulation of non-international armed conflicts.

A significant study of International Customary Humanitarian Law by the International Committee of the Red Cross (hereinafter - the ICRC) have brought some clarity in what rules exactly can be held as part of it. Customary law study per se does not impose any obligations based on customary law. Nonetheless, the ICRC being quite an authoritative body, it has been rendering the recognition of international community.

\subsubsection{Environmental customary humanitarian law rules}

The Rule 42 of the Customary Law Study contains duty of particular care when launching an attack against works and installations containing dangerous forces. According to the study, this norm is applicable in both international and non-international armed conflicts. ${ }^{42}$ It does not impose a complete prohibition, but obligation of care is always to be considered before the attack.

The Rule 43 prohibits attacks on the natural environment in the NIACs as well as in the IACs unless it is justified by a military necessity or elements of the environment become a military object ${ }^{43}$. Normally, natural environment is considered to be a civilian object. ${ }^{44}$ Hostilities, however, can change its use or purpose ${ }^{45}$ and then general principles of the IHL come in use. The Customary Law Study also makes the link between environmental protection and protection of the property in Rule 50. ${ }^{46}$ This prohibition of the destruction of property, not justified by the military necessity, is applicable in internal armed conflicts, as well.

However, as for the Rule 44 and the Rule 45, there is a lack of state practice to establish undisputable rule of customary law, but enough of state practice to determine the movement towards this direction. The former rule regulates use of means and methods of warfare. The latter prohibits the use and means of weapons intended to cause

41 Hampson, F. J., supra note 40, p. 177.

42 Henckaerts, J. M. and Doswald-Beck, L. Customary International Humanitarian Law. International Committee of the Red Cross, Vol. I, Rules. New York: Cambridge University Press, 2009, p. 139.

43 Ibid., p. 143.

44 Henckaerts, J. M. Study on Customary International Humanitarian Law: A Contribution to the Understanding and Respect for the Rule of Law in Armed Conflict. International Review of the Red Cross. 2005, (87): 175-212, also see p. 191.

45 More about location, purpose and use, see in Solis, G. D. supra note 1, p. 524-528.

46 Henckaerts, J. M. and Doswald-Beck, L., op. cit., p. 175. 
widespread, long-term and severe damage to the natural environment. The Rule 44 applies in the NIAC undoubtedly only if "there ARE effects in another state. (emphasis added)" ${ }^{\prime 47}$ The emphasis suggests that a negative impact on the environment is already present. This is only post factum application of the rule. It is not meant to protect, more to establish the responsibility.

Other customary rules, providing higher protection for the environment in the NIAC, are rules on weapons and their prohibition. Since weapons' conventions (see section 1.1.3.) only bind parties to them, certain rules of weapons conventions have developed into customary norms, applicable in both the IACs and the NIACs. Laid down in the rules 70-76 of the Customary Law Study, they impose obligations of all the states, regardless of their membership in a certain convention, thus indirectly increasing the level of the environmental protection in the NIACs.

\subsubsection{General IHL Principles}

The main principles of IHL - distinction, unnecessary suffering, proportionality and military necessity - are deeply settled in the international humanitarian customary law. Although GCs, where general IHL principles also are explicitly laid down, are not applicable in the NIAC as a whole, these principles, expressed in the rules 7-14 of the customary law study, are considered as applicable in international and internal armed conflicts, as well. Therefore, even if certain customary law provisions are not applicable in internal armed conflicts or do not cover gaps in treaty obligations, the environmental protection falls under the protection of the main IHL principles.

As it has been mentioned before, the elements of the environment are considered as civilian objects. ${ }^{48}$ This is not an absolute prohibition. Attacks against civilian objects are prohibited unless it is justified by the military necessity. Bothe, Bruch, Diamond and Jensen in their article name one of the main issues when applying the main IHL principles - transformation of the environmental elements into military objectives. Such transformation may justify attacks against the environment directly; therefore, such transformation should be prevented. ${ }^{49}$ Measures for the prevention may be in a form of amending rules of engaging in hostilities, imposing absolute prohibitions on military units, e.g. a prohibition to use a forest as a disguise. Another crucial issue is environmental damage as collateral damage. "Where damage occurs outside military objectives (for example an oil spill caused by the attack against the power station situated near the coast), it [...] is quite difficult to assess environmental damage." ${ }^{50}$

After analyzing all relevant international customary humanitarian law rules, it can be inferred that the protection which can be used on the environment in times of non-

47 Henckaerts, J. M. and Doswald-Beck, L., supra note 42, p. 148.

48 Bothe, M.; Bruch, C.; Diamond, J. and Jensen, D., supra note 2;

Henckaerts, J. M., supra note 42, p. 191.

49 Bothe, M.; Bruch, C.; Diamond, J. and Jensen, D., op. cit., p. 577.

50 Bothe, M.; Bruch, C.; Diamond, J. and Jensen, D., supra note 2. 
international armed conflicts is mostly concentrated on considering elements of the environment as civilian objects. However, the majority of such rules have not reached enough of support in state practice to be recognized as customary law rules. The main impediments are the possibility to transform the environmental elements into the military objectives by their use (which then makes them fall under the scope of military necessity principle) and the lack of clarity applying principle of proportionality when the collateral damage is caused by the attacks on legitimate targets. Nonetheless, customary law can be considered as one of the most useful instruments for the environmental protection in times of the NIAC.

\section{Evaluating the Law}

After the analysis of relevant treaties and customary law, it is now possible to identify deficiencies and merits of law of a non-international armed conflict when it comes to the protection of the environment and to make inferences on its integrity. In this section, the results of this research will be summarized, answering the question whether a legal framework providing the sufficient environmental protection in times of internal armed conflict exists.

Despite the number of legal instruments, which can be related to the environment in the NIAC, the environment does not function as an independent subject of protection. Most of the provisions require interpretation or to be linked to civil objects as subjects of the protection. The protection is invoked as a post factum matter, not as a preventive matter. Some documents are indirectly applicable to internal environmental issues only due to the application in other fields, such as disarmament, protection of civilian objectives and protection of property. Certain documents, such as the AP II, set very high threshold for the application of this document as such, and, therefore, makes it more difficult to apply even the vaguest norms that could favor the environment in the NIAC.

Environmental law of war, and especially of non-international "war", is very much dependent on customary humanitarian law principles. ${ }^{51}$ However, these principles lack authoritativeness. The principle of the military necessity tends to supersede other objectives.

Available instruments are also incoherent, dispersed in too many types of sources and in too many agreements. ${ }^{52}$ Terms, that describe environmental damage, which could be prerequisite for the responsibility, (therefore, subject for this protection post factum), are vague and lack specification. It gives the room for interpretation, which can, and mostly do, vary not in the advantage of the environment.

Back to the beginning of the 90 's, initiative to take care of the negligent regulation of the environment in times of war took place in the form of the proposal for the Fifth

51 Falk, R. The Environmental Law of War: an Introduction. Environmental Protection and the Law of War. London: Belhaven Press, 1992, p. 93.

52 Ibid., p. 66. 
Geneva Convention on the Protection of the Environment in Time of Armed Conflict. ${ }^{53}$ It would have been the document, which had not made the distinction between the NIAC and the IAC. Proposals included requirements to avoid environmental damage, regardless of its connection to any other objects of the protection. They concerned the application of principle of proportionality and the military necessity. Moreover, the proposals referred to the criterions of "wide-spread, long term and severe" in ENMOD Convention and AP I as being too high of the requirement. ${ }^{54}$

However, this initiative was turned down, which, according to the author's opinion, is simply based on the unwillingness of the states to recognize damage to the environmental elements as the matter of as much concern as other negative consequences or effects of war. Customary humanitarian law, in this perspective, cannot do much change either, since it is completely dependent on the state practice.

Therefore, the overall assessment of the existing framework for the environmental protection during internal wars cannot be positive. Fortunately, it also cannot be claimed that the environment in a non-international conflict is completely abandoned. There are rules ensuring the very minimal protection. This minimal protection, however, does not amount to the effective legal regime.

\section{Building a New Regime. Suggestions for the Improvement}

In order to upgrade the current system, ex post mechanisms have to be introduced as much and as effectively as ex ante ones. New and/or improved statutory obligations should avoid indeterminacy. A crucial role has to be granted to transforming the approach of states and societies with the aim of prioritizing environmental concerns. Further in section 3, possible measures of achieving abovementioned purposes are described.

\subsection{Civil liability}

When the environmental consequences of an internal war get in the way of post war recovery, it is usually the monetary problems that states are facing. Therefore, civil liability for entities responsible for environmental devastation, when such liability is imposed by a specific international organ, would help solving the problem. "Civil compensation has the potential to provide a rapid and satisfactory route by which environmental damage caused during armed conflict may be redressed as soon as possible after it occurs." ${ }^{, 5}$

One of the possible means to implement such a measure would rely on the example of the United Nations Compensation Commission (hereinafter - the UNCC) - an

53 Gasser, P., supra note 3, p. 639.

54 Turk, H. The Negotiation of a New Geneva-style Convention: a Government Lawyer's Perspective. Environmental Protection and the Law of War. London: Belhaven Press, 1992, p. 98-103.

55 Smith, T. Criminal Accountability or Civil Liability: Which Approach Most Effectively Redresses the Negative Environmental Consequences of Armed Conflict? International Law and Armed Conflict. Challenges in the 21st Century. The Hague: Asser Press, 2010, p. 95-114, see p. 104. 
independent system established to provide compensations for damage in the IraqKuwait armed conflict. Claims for the environmental damage are also included in the Commission's framework. ${ }^{56}$

With a compensational system model similar to the UNCC, belligerent parties would see the costs of the conflict, realize them rising. Therefore, they might choose either to cease the hostilities entirely or modify their means and methods of warfare to ensure that the least possible level of damage to the environment is caused. ${ }^{57}$ Such a compensational body could accept claims submitted by governments and international organizations representing non-governmental belligerent parties, thus not excluding possibilities to bring claims arising in the situations of an internal armed conflict. If subjects of the claims were not only governments, but also other entities, such as organized rebel groups and their leaderships, it would increase the assurance that the non-governmental belligerent party would assess its combat plans, as well. Full-time functioning of this kind of body, not being limited to one particular issue, would encourage belligerent parties, simply talking, to think before acting.

Another suggestion, likewise concerning civil liability, would be to create an international insurance scheme. ${ }^{58}$ Such a scheme would receive contributions in a form of international mandatory states' payments or as part of states' taxation system, specifically aimed for creating the insurance fund. The use of the fund would be possible in a case of the need to support carrying out environmental post war clean ups and restorations.

\subsection{Focus on existent legal framework and national legislations}

Although present rules of the environmental protection in times of an internal conflict are far from sufficient, it is still crucial to develop society's respect for them by way of teaching international law, incorporating it into military manuals and training.

While some rules concerning the issue are only approaching customary law status and the level of the rules being binding is limited, states can always adopt certain practices under the national law. Legal standards in the national legislation can go further than rather narrow international obligations. ${ }^{59}$ Since the NIACs are primarily the sovereign matter of the state, sovereign legislation imposing criminal and/or civil liability for military commanders would most likely be effective.

56 Category "F" Claims. The UN Compensation Commission. Geneva, 2013 [interactive]. [accessed on 0607-2013]. <http://www.uncc.ch/claims/f_claims.htm>.

57 Smith, T., op. cit., p. 104;

58 Drumbl, M. A. Waging War against the World: the Need to Move from War Crimes to Environmental Crimes. Environmental Consequences of War. Legal, Economic and Scientific Perspectives. Cambridge, New York, Melbourne, Madrid: Cambridge University Press, 2000, p. 620-646, see p. 644.

59 Roberts, A. The Law of War and Environmental Damage. Environmental Consequences of War. Legal, Economic and Scientific Perspectives. Cambridge, New York, Melbourne, Madrid: Cambridge University Press, 2000, p. 47-86, see p. 77. 


\subsection{Changes in the International Criminal Law}

During the negotiations ${ }^{60}$ on the new substantial treaty for the environmental protection in times of war, suggestions have been made for establishing international crimes against the environment. ${ }^{61}$ Taking into account that these negotiations took place in early 90's, some changes, such as the adoption of the Rome Statute, were implemented in International Criminal Law since then. However, the need for international crimes against the environment in the NIACs was not taken into consideration. Therefore, a suggestion in favour of the environmental damage control would be the amendment of the ICC statute including a provision, similar to 8 (2) (b) (iv), to the list of war crimes committed in internal conflicts.

M. A. Drumbl raises an issue that could emerge upon certain changes. He says that "magistrates and judges of the International Criminal Court likely will not have expertise in the areas of environmental law, policy, or science (...)." ${ }^{\prime 2}$ This could invoke an increase of the costs of proceedings and ineffective jurisprudence. The logical question then is whether the appropriate solution would be an establishment of the new international tribunal in particular for environmental crimes. C. Ripa di Meana in the same above mentioned negotiations contribute to this idea. ${ }^{63}$ Establishment of an arbitration institution, dealing with environmental claims not only in times of war, regardless of internal or international, but also in the peace time, would be another option. The question is whether modern society is ready for such drastic changes and whether states are ready to sacrifice a level of their sovereignty for the protection of the environment.

\subsection{The need of a new comprehensive document}

In June, 1991 the London Round Table Conference on 'A "Fifth Geneva" Convention on the Protection of the Environment in Time of Armed Conflict', which would be applicable not only in the IACs, but also in the NIACs, was organized. Although the conference did end in the proposal for a new document, such document is still only in the minds of environmental lawyers. However, it does not mean that the need of its adoption has become absent. Properly arranged and formulated with the support of the states, the new comprehensive document would be the most beneficial contribution favoring the environmental protection in times of war.

Notwithstanding the unproductive outcome of the conference, suggestions for a new document have been expressed in several contributions of authors even a decade

60 The London Round Table Conference on "A "Fifth Geneva" Convention on the Protection of the Environment in Time of Armed Conflict.' Read about the conference in more detail in the following section.

61 Turk, H., supra note 54, p. 99.

62 Drumbl, M. A., supra note 58, p. 640.

63 Ripa di Meana, C. Environmental Protection and the Law of War. Introductory Speech. London: Belhaven Press, 1992, p. 65-67. 
later. ${ }^{64}$ Adding up the proposals, there are three forms in which the new instrument could be adopted - as the 5th Geneva Convention, as the IV ${ }^{\text {th }}$ Additional Protocol to Geneva Conventions ${ }^{65}$ and as the Ecocide Convention ${ }^{66}$ (following the example of the Genocide Convention, applicable in times of war as well as in peace time and criminalizing the environmental damage). Turk and Falk pointed out that regardless of the form taken, the new instrument should consider the following elements ${ }^{67}$ :

- Firstly, and most importantly, including non-international armed conflicts under the scope of its regulation.

- Relation of the environmental damage and principles of proportionality and military necessity. Evocation of these principles should be declared more precisely than only leaving it for the margin of appreciation of military commanders. Even with the adoption of this new instrument or criminalization of environmental damage in the NIAC, absence of the determination would lead to the same initial problem of the IHL principle of military necessity overweighting environmental devastation.

- Maintaining the prohibitions of disarmament treaties and focusing on the use of these weapons.

- Answering the question whether only intentional actions lead to the prosecutable and/or punishable consequences or the rules also should include the negligence.

- $\quad$ Specifying types of harm, degrees of responsibility and liability.

- Introducing the definition of protected areas, sites, objects, natural processes. It could be done by providing the general definitions or made as a form of a list of protected properties that could be considered as Natural Heritage (similarly to World Heritage List, provided by the World Heritage Convention).

- Either establishing new grave environmental breaches of the convention, criminalizing environmental devastation not only in the IAC, but in the NIAC as well, or introducing the notion of ecocide.

- Establishing a new body ensuring execution of the new instrument compensatory and/or (semi)judicial.

The creation of a new legal instrument would definitely be a major contribution to the sufficiency of the legal framework protecting the environment in times of the NIACs. However, creating an effective and sufficient legal regime is not limited to achieving this adoption. The process will be successful only if international opinion is supportive of the regime. All this requires a thorough and long negotiation process and achievement of genuine consensus among the governments.

64 Brunch, C. E. Environmental Consequences of War. Legal, Economic and Scientific Perspectives. Introduction to Part IIA. Cambridge: Cambridge University Press, 2000, p. 39-46, see p. 45; Falk, R., supra note 51, p. 155; Drumb1, M. A., supra note 61, p. 643.

65 Turk, H., supra note 54, p. 101.

66 Brunch, C. E., op. cit.

67 Turk, H., op. cit., p. 98-103; Falk, R. op. cit., p. 155. 


\section{Conclusions}

1. Despite the slowly growing concern on the issue, environmental devastation in times of internal conflict still is an underestimated consequence of the hostilities.

2. Environmental protection in times of NIAC is regulated by a number of incoherent, implicit and quite vague norms that are dispersed in too many types of sources among humanitarian law, international environmental law, international criminal law and human rights law. Elements of environment are not independent subjects of protection and have to be linked to other subjects of protection, such as civilian objects or human rights.

3. The current legal framework is not sufficient for a proper regulation of environmental protection times of internal armed conflict.

4. Improvements of the legal framework could have the form of:

a. Creation of the compensational system model or establishing international insurance scheme, which would prevent potential harms to the environment as well as would help in post-war recovery processes.

b. Adopting changes in international criminal law in order to establish international environmental crimes in internal conflicts.

c. Encouraging states to amend their national legislations.

d. Adopting a new comprehensive document, exhaustively addressing all the issues and obstacles related to the regulation and implementation of the environmental preservation in times of non-international armed conflicts.

\section{References}

Amendment of the Article 1.2 of 1980 Convention on Prohibition or Restrictions on the Use of Certain Conventional Weapons which may be Deemed to be Excessively Injurious or to have Indiscriminate Effects (adoption 21 December, 2001, entry into force 18 May, 2004) 2260 U.N.T.S. 82.

Bothe, M.; Bruch, C.; Diamond, J. and Jensen, D. International Law Protecting the Environment During Armed Conflict: Gaps and Opportunities. International Review of The Red Cross. 2010, (92): 569-592.

Bouvier, A. Protection of the Environment in Time of Armed Conflict. International Review of the Red Cross. 1991, (73): 599611.

Bouvier, A. Protection of the Environment in Time of Armed Conflict. Report submitted by the ICRC for the $47^{\text {th }}$ session of the United Nations General Assembly. 1 October, 1992.

Brunch, C. E. Introduction. Environmental Consequences of War. Legal, Economic and Scientific Perspectives. Cambridge, New York, Melbourne, Madrid: Cambridge University Press, 2000.

Cullen, A. The Concept of Non-International Armed Conflict in International Humanitarian Law. New York: Cambridge University Press, 2010.

Convention on the Prohibition of the Development, Production, Stockpiling and Use of Chemical Weapons (adopted 3 September, 1992, entry into force 29 April, 1997). 1974 U.N.T.S. 317.

Convention on the Prohibition of the Development, Production and Stockpiling 
of Bacteriological (Biological) and Toxin Weapons and on Their Destruction (adopted 10 April, 1972, entry into force 26 March, 1975). 1015 U.N.T.S. 163 / [1977] ATS 23 / 11 ILM 309 (1972).

Convention on the Prohibition of Military or Any Other Hostile Use of Environmental Modification Techniques (adopted 10 December, 1976, entry into force 5 October, 1978). 1108 U.N.T.S. 151.

Convention on Prohibitions or Restrictions on the Use of Certain Conventional Weapons which may be deemed to be Excessively Injurious or to have Indiscriminate Effects, (adopted 10 October, 1980, entry into force 2 December, 1983). 1342 U.N.T.S. 137/ [1984] ATS 6 / 19 ILM 1823 (1980).

Declaration of the United Nations Conference on the Human Environment (adopted at the United Nation Conference on Human Environment in Stockholm, 16 June, 1972). 11 I.L.M. 1416 (1972).

Drumbl, M. A. Waging War against the World: the Need to Move from War Crimes to Environmental Crimes. Environmental Consequences of War. Legal, Economic and Scientific Perspectives. Cambridge, New York, Melbourne, Madrid: Cambridge University Press, 2000, p. 620-646.

European Convention on Human Rights (adopted by Council of Europe at 4 November, 1950, entry into force 3 September, 1953). 213 U.N.T.S. 222.

Falk, R. The Environmental Law of War: An Introduction, in Plant, G. (ed.). Environmental Protection and the Law of War. London: Belhaven Press, 1992, p. 7895.

Final Report to the Prosecutor by the Committee Established to Review the NATO Bombing Campaign Against the Federal Republic of Yugoslavia. The International Criminal Tribunal for Former Yugoslavia. 13 June, 2000 [interactive]. [accessed on 06-072013]. <http://www.icty.org/sid/10052/en>.

Gasser, H. P. For Better Protection of Natural Environment in Armed Conflict: a
Proposal for Action. American Journal of International Law. 1995, (89): 637-643.

Geneva Convention (I) for the Amelioration of the Condition of the Wounded and Sick in Armed Forces in the Field (adopted 12 August, 1949, entry into force 21 October, 1950). 75 U.N.T.S. 31/ [1958] ATS No 21.

Geneva Convention (II) for the Amelioration of the Condition of Wounded, Sick and Shipwrecked Members of Armed Forces at Sea (adopted 12 August, 1949, entry into force 21 October, 1950). 75 U.N.T.S. 85/ [1958] ATS No 21.

Geneva Convention (III) Relative to the Treatment of Prisoners of War (adopted 12 August, 1949, entry into force 21 October, 1950). 75 U.N.T.S. 135/ [1958] ATS No 21.

Geneva Convention (IV) Relative to the Protection of Civilian Persons in Time of War (adopted 12 August, 1949, entry into force 21 October, 1950). 75 U.N.T.S. 287/ 1958 ATS No 21.

Gleditch, N. P. Armed Conflict and the Environment: A Critique of the Literature. Journal of Peace Research. 1998, (35): 381-400.

Hampson, F. J. The Relationship Between International Humanitarian Law and Human Rights Law From The Perspective of a Human Rights Treaty Body. International Review of a Red Cross. 2008, (90): 549-572. World Health Organization. Health Aspects of Chemical and Biological Weapons. Geneva, 1970 [interactive]. [accessed on 06-07-2013]. <http://www.who.int/csr/ delibepidemics/en/Chapters1 to6.pdf $>$.

Henckaerts, J. M. Towards Better Protection for the Environment in Armed Conflict: Recent Developments in International Humanitarian Law. The Review of European Community and International Environmental Law. 2000, (9): 13-19.

Henckaerts, J. M. Study on Customary International Humanitarian Law: A Contribution to the Understanding and Respect for the Rule of Law in Armed Conflict. International Review of the Red Cross. 2005, (87): 175-212. 
Henckaerts, J. M. and Doswald-Beck, L. Customary International Humanitarian Law. International Committee of the Red Cross, Vol. I, Rules. New York: Cambridge University Press, 2009.

Henckaerts, J. M. and Doswald-Beck, L. Customary International Humanitarian Law. International Committee of the Red Cross, Vol. II, Practice, Part 1. New York: Cambridge University Press, 2005.

High Level Expert Meeting on the New Future of Human Rights and Environment: Moving the Global Agenda Forward. United Nations Environmental Programme. 2009 [interactive]. [accessed on 06-07-2013]. <http://www.unep. org/environmentalgovernance/Events/ HumanRightsandEnvironment/tabid/2046/ language/en-US/Default.aspx>.

International Covenant on Civil and Political Rights (adopted and opened for signature, ratification and accession by the UN General Assembly resolution 2200A (XXI) of 16 December, 1966, entry into force 26 March, 1976). 999 U.N.T.S. 171.

Kiss, A. International Humanitarian Law and the Environment. Environmental Policy and Law. 2001, (31): 223-231.

Legal Consequences of the Construction of Wall in the Occupied Palestinian Territory. International Court of Justice, Advisory Opinion I. C. J. Reports 2004, PP. 136-203.

Peterson, I. The Natural Environment in Times of Armed Conflict: A Concern for International War Crimes Law? Leiden Journal of International Law. 2009, (22): 325-343.

Protocol Additional to the Geneva Conventions of 12 August, 1949, and relating to the Protection of Victims of International Armed Conflicts (Protocol I) (adopted 8 June, 1977, entry into force 7 December, 1978). 1125 U.N.T.S. 609.

Protocol Additional to the Geneva Conventions of 12 August, 1949, and relating to the Protection of Victims of NonInternational Armed Conflicts (Protocol
II) (adopted 8 June, 1977, entry into force 7 December, 1978). 1125 U.N.T.S. 609/ [1991] ATS 30/16 ILM 1442 (1977).

Protocol on Non-Detectable Fragments (Protocol I) (adopted 10 October, 1980, entry into force 2 December, 1983). 1342 U.N.T.S. 168, 19 I.L.M. 1529.

Protocol on Prohibitions or Restrictions on the Use of Mines, Booby-Traps and Other Devices (adopted 10 October, 1980, entry into force 2 December, 1983) 1342 U.N.T.S. 168, 19 I.L.M. 1529.

Protocol on Prohibitions or Restrictions on the Use of Incendiary Weapons (adopted 10 October, 1980, entry into force 2 December, 1983). 1342 U.N.T.S. 171, 19 I.L.M. 1534.

Resolution A/RES/47/37 on the Protection of the environment in times of armed conflict. The UN General Assembly. Adopted 1125-1992 [interactive]. [accessed on 0607-2013]. <http://www.un.org/Depts/dhl/ resguide/r47.htm $>$.

Review Conference of the Rome Statute. Coalition to the International Criminal Court Kampala, 2010 [interactive]. [accessed on 06-06-2013]. <http://www.iccnow. org/?mod=review $>$.

Rio de Janeiro Declaration on Environment and Development (adopted at Rio de Janeiro Declaration on Environment and Development in Rio de Janeiro, 13 June, 1992). 31 I.L.M. 881 (1992).

Ripa di Meana, C. Environmental Protection and the Law of War. Introductory Speech. London: Belhaven Press, 1992, p. 65-67.

Roberts, A. The Law of War and Environmental Damage. Environmental Consequences of War. Legal, Economic and Scientific Perspectives. Cambridge, New York, Melbourne, Madrid: Cambridge University Press, 2000, p. 47-86.

Shaw, M. N. International Law. New York: Cambridge University Press, 2008.

Smith, T. Criminal Accountability or Civil Liability: Which Approach Most Effectively Redresses the Negative Environmental Consequences of Armed Conflict? 
International Law and Armed Conflict. Challenges in the 21st Century. The Hague, 2010, p. 95-114.

Solis, G.D. The Law of Armed Conflict. International Humanitarian Law in War. New York: Cambridge University Press, 2010.

Tarasofsky, R. G. Legal Protection of the Environment during International Armed Conflict. Netherlands Yearbook of International Law. 1993: 17-79.

The Charter of the United Nations and Statute of International Court of Justice (adopted 26 June, 1945, entry into force 24, October 1945), 1 U.N.T.S. XVI. Available at the UN Treaty Collection [interactive]. [accessed on 06-07-2013]. <http://treaties.un.org/doc/ Publication/CTC/uncharter.pdf $>$.

The International Committee of the Red Cross. Geneva, 2013 [interactive]. [accessed on 0607-2013]. <http://www.icrc.org/eng/index. jsp>.
The Rome Statute for the International Criminal Court (adopted 17 July, 1998, entry into force 1 July, 2003). 2187 U.N.T.S. 90.

The UN Compensation Commission. Geneva, 2013 [interactive]. [accessed on 06-072013]. <http://www.uncc.ch/claims/f_ claims.htm>.

United Nations Treaty Collection [interactive]. [accessed on 06-07-2013]. <http://treaties. un.org/home.aspx>.

Verwey, W. D. Protection of the Environment in Times of Armed Conflict: In Search of a New Legal Perspective. Leiden Journal of International Law. 1995, (8): 7-40.

Voneky, S. Peacetime Environmental Law as a Basis for State Responsibility. Environmental Consequences of War. Legal, Economic and Scientific Perspectives. Cambridge, New York, Melbourne, Madrid: Cambridge University Press, 2000, p. 190225.

\title{
APLINKOS APSAUGA NETARPTAUTINIO KARINIO KONFLIKTO METU: TEISINIS REGLAMENTAVIMAS, JO IŠSAMUMAS BEI PASIÜLYMAI DÉL JO TOBULINIMO
}

\author{
Indrè Lechtimiakyte
}

Groningeno universitetas, Nyderlandai

Santrauka. Aplinkos apsauga kariniu konfliktu, tiek regioniniu, tiek tarptautiniu, metu tarptautineje humanitarineje teiseje nèra laikoma vienu is prioritetu. Tai ypač problemiška, kai kalbame apie regioninius (netarptautinius) karinius konfiktus - nepriklausomos valstybès suverenitetas leidžia jai savo teritorijos ribose turèti tam tikra veiksmu laisvę. Istorija ir tarptautiniai teisès aktai rodo, jog net ir žmogaus teisiu pažeidimai turi pasiekti tam tikra sunkumo lygi, kad bütu pateisinta intervencija i suverenios valstybes teritorija, todèl nenuostabu, jog šiandienine visuomene juo labiau nèra linkusi atkreipti dèmesį ż žala, tokiu konfliktu metu daroma aplinkai. Sudètinga surasti ne tik išsamiu teises normu, kurios reglamentuotu aplinkosauga netarptautiniu kariniu veiksmu metu, bet ir moksliniu publikaciju. Teises spragos paprastai patraukia mokslininku dèmesí, jie linkę analizuoti teisinius vakuumus ir siülyti galimus problemu sprendimu büdus. Publikaciju aplinkosangos regioninio konflikto metu tema rasti beveik neimanoma. 
Dèl minètu priežasčiu šiame straipsnyje apžvelgiamos rašytinès ir paprotinès teisès normos, kurias galima rasti ne tik humanitarinès teises, bet ir kitu tarptautines teisès šaku, tokiu kaip žmogaus teisiu teise, aplinkosangos teisè, baudžiamoji teise, dokumentuose. Analizuojamas šiu teisès normu bei humanitarinès teisès principu (karinès bütinybès, proporcingumo, atskyrimo), kurie, deja, paprastai igauna pirmenybę kariniuose veiksmuose, santykis; taip pat taikos metu galiojanču teises normu taikymo karinio konflikto metu aspektai. Surinkus informaciją apie ivairiu tarptautines teises šaku teises normas, tiesiogiai ar netiesiogiai reglamentuojančias aplinkos apsauga regioninio konflikto metu, daroma išvada dèl tokio reglamentavimo nepakankamumo ir jo tobulinimo poreikio.

Norint užtikrinti išsamu ir visapusiška teisinị reglamentavima ir tokio reglamentavimo igyvendinima, pateikiami siülymai dèl teisines bazes tobulinimo. Tai tarptautines civilinès atsakomybès aplinkosaugos srityje kürimas, pokyčiu tarptautineje baudžiamojoje teisèje inicijavimas, naujo, išsamaus tarptautinio dokumento (sutarties, konvencijos ar dar vieno papildomo protokolo prie Ženevos konvenciju), reglamentuojančio aplinkosauga ne tik taikos, bet ir kariniu veiksmu, tiek regioniniu, tiek tarptautiniu, metu priemimas. Taip pat pokyčiai, galimi inicijuoti ir pačiu šaliu, ìtraukiant aplinkosangos normas $i$ kariniu vadoveliu puslapius ar nustatant baudžiamają atsakomybę nacionaliniu lygiu, kai žala aplinkai valstybès teritorijoje dèl kariniu veiksmu viršija nustatyta lygmeni.

Reikšminiai žodžiai: aplinkos apsauga, humanitarine teise, aplinkos apsaugos teisè, žmogaus teisiu teisè, tarptautinè baudžiamoji teisé, netarptautinis (regioninis) karinis konfliktas, tarptautinio reglamentavimo nepakankamumas, teisinis vakuumas.

Indrè Lechtimiakytė, Mykolo Romerio universiteto ir Groningeno universiteto (Nyderlandai) absolventė (tarptautinès teisès bei tarptautinių organizacijų teisės (LL.M) laipsnis). Mokslinių tyrimų kryptis: tarptautinè viešoji teisè.

Indrè Lechtimiakytė, graduate of Mykolas Romeris University and University of Groningen (the Netherlands), LL.M. in International Law and Law of International Organizations. Research interest: public international law. 